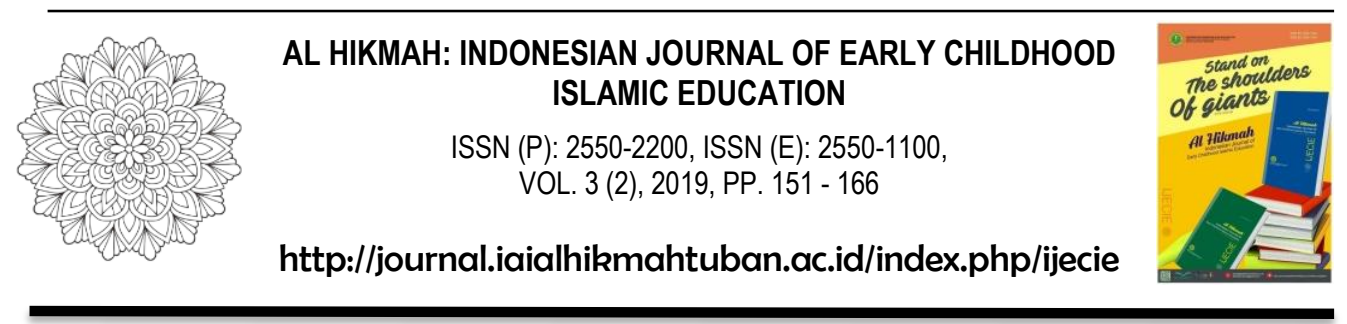

\title{
PEMANFAATAN GRUP WHATSAPP SEBAGAI MEDIA INFORMASI PROSES BELAJAR ANAK DI KB PERMATA BUNDA
}

\author{
Nur Lailatul Fitri \\ Prodi Pendidikan Islam Anak Usia Dini, STAI Al Hikmah Tuban \\ Ila.elfitri88@gmail.com
}

\begin{abstract}
Abstrak
Penelitian ini bertujuan untuk mendeskripsikan: 1) bagaimana penyampaian informasi proses belajar anak di KB Permata Bunda ? 2) bagaimana pemanfaatan grup whatsapp ? 3) apa dampak positif dan negative dari pemanfaatan grup whatsapp sebagai media informasi ? Metode pengumpulan data 'berupa observasi, wawancara, dan dokumentasi. Hasil penelitian menunjukkan: 1) penyampaikan informasi perkembangan akademik di KB Permata Bunda Gesikharjo adalah dengan melalui buku penghubung yang dibagikan setiap 3 bulan sekali, sedangkan yang berkaitan dengan proses KBM melalui surat, pertemuan, dan pesan. 2) group whatsapp dimanfaatkan sebagai penghubung harian antara guru dan wali murid. 3) beberapa dampak positif dirasakan oleh orang tua siswa KB Permata Bunda Gesikharjo diantaranya mereka dapat mengetahui informasi perkembangan anak di sekolah secara cepat meskipun mereka mempunyai kesibukan lain diluar sekolah, sedangkan dampak negatifnya lebih berkaitan dengan waktu dan tata bahasa dalam komunikasi tertulis.
\end{abstract}

Kata Kunci: Grup whatsapp, media informasi, Proses Belajar

\section{Abstract}

This study aims to describe: 1) how is the delivery of information on the learning process of children at KB Permata Bunda? 2) how to use whatsapp group? 3) what are the positive and negative impacts of using whatsapp groups as information media? The data collection method is in the form of observation, interview and documentation. The results showed: 1) the delivery of information on academic development at KB Permata Bunda Gesikharjo was through a contact book that was distributed once every 3 months, while those related to the KBM process through letters, meetings and messages. 2) whatsapp group is used as a daily link between teacher and student guardians. 3) some positive effects felt by parents of KB Bunda Gesikharjo KB students including they can find out information on children's development at school

THIS WORK IS LICENSED CREATIVE COMMONS ATTRIBUTION-NONCOMMERCIAL 4.0 INTERNATIONAL LICENSE@ 2019 PROGRAM STUDI PENDIDIKAN ISLAM ANAK USIA DINI, STAI AL HIKMAH TUBAN, JAWA TIMUR 
quickly even though they have other activities outside of school, while the negative impact is more related to time and grammar in written communication.

Keywords: Whatsapp Group, media informa, learning process.

\section{PENDAHULUAN}

Rumah adalah madrasah atau sekolah pertama bagi anak. Didalamnya orang tua dan anggota keluarga lain yang berperan menjadi guru pertama bagi anak. Disamping itu, selain dalam keluarga, anak juga hidup di sekolah. Atas dasar ini baik orang tua maupun guru di sekolah harus memahami posisi anak, agar keduanya bisa saling bersinergi, yakni sekolah dapat melanjutkan peran orang tua di rumah, dan orang tua bisa melanjutkan program sekolah di rumah.

Pada dasarnya setiap orang tua menginginkan anaknya memiliki perilaku yang baik, mempunyai sikap sosial yang positif, diterima oleh teman-teman sekelompoknya, serta mampu mencapai perkembangan yang optimal. Hal yang sama juga diinginkan oleh guru. Akan tetapi, setiap keluarga atau orang tua memiliki latar belakang yang berbeda.

Perkembangan anak-anak pada usia awal lebih banyak akibat pengaruh dari lingkungan keluarga atau suasana di dalam rumah. Selain itu, kondisi ibu juga berpengaruh pada perkembangan anak. Hal ini disebabkan karena kesibukan ibu untuk mencari nafkah tambahan. Ibu yang bekerja umumnya hanya dapat mengantar anak dan tidak bisa menunggui anaknya ketika di PG, KB, atau TPA, atau bahkan ada yang mengantar saja tidak sempat karena kesibukannya. Oleh karenanya, guru di lembaga PAUD harus mampu menjalin komunikasi dan membangun kerjasama dengan orang tua siswa secara baik. Selain untuk mengoptimalkan perkembangan anak, hal tersebut juga dapat digunakan guru untuk mengetahui seberapa besar 
pengetahuan orang tua terhadap anaknya dan tentang program-program di sekolah.

Penyampaian informasi perkembangan anak serta program-program di sekolah dari tahun ke tahun mengalami perkembangan. Dari mulai penyampaian secara lisan, membuat pengumuman yang ditempel di papan informasi atau di pintu kelas, membuat surat undangan, pertemuan wali murid, pencatatan perkembangan anak pada buku laporan perkembangan anak, hingga sekarang yang paling popular adalah melalui aplikasi pada smartphone, seperti whatsapp (WA). Whatsapp menjadi salah satu media informasi yang banyak digunakan oleh berbagai kalangan, termasuk antara guru dan wali murid. Penyampaian informasi melalui grup whatsapp ini dimaksudkan agar apa yang disampaikan oleh guru bisa mudah dan cepat tersampaikan kepada orang tua. Namun dalam praktiknya, terkadang masih ditemui beberapa kendala. Misalnya tidak ada respon dari orang tua, atau kesalahpahaman dalam menerima informasi karena bahasa tulis yang digunakan oleh guru terkadang disingkat-singkat.

Berdasarkan latar belakang ini, penulis tertarik untuk mengamati tentang pemanfaatan grup whatsapp sebagai media informasi proses belajar anak di kelompok bermain Permata Bunda desa Gesikharjo. Adapun rumusan masalah dalam penelitian ini adalah: 1) bagaimana penyampaian informasi proses belajar anak di KB Permata Bunda ? 2) bagaimana pemanfaatan grup whatsapp ? 3) apa dampak positif dan negative dari pemanfaatan grup whatsapp sebagai media informasi ?

\section{Pemanfaatan Aplikasi Whatsapp}

Whatsapp adalah aplikasi pesan lintas platform yang memungkinkan kita bertukar pesan tanpa biaya SMS, karena whatsapp menggunakan paket data internet yang sama untuk email, browsing web dan lain-lain (Enterprise, 
2012). Whatsapp messenger menggunakan koneksi 3G/4G atau WIFI untuk komunikasi data.

Dari tahun ke tahun, aplikasi whatsapp selalu memanjakan penggunanya. Tepatnya pada tanggal 22 Januari 2015, aplikasi ini meluncurkan Whatsapp Web. Aplikasi ini memfasilitasi whatsapp untuk pengguna berbasis computer atau personal computer. Seperti halnya whatsapp pada telepon seluler, Whatsapp Web juga membutuhkan koneksi internet sebagai jalur penyampaian informasi. Pada prinsipnya Whatsapp Web berfungsi untuk membuka akun whatsapp melalui perangkat computer. Untuk membuka akun Whatsapp Web ini dibutuhkan sinkronisasi. Ada barcode atau kumpulan data optic yang akan dibaca mesin pemindai melalui aplikasi Whatsapp mobile. Kemudian pemindaian akan secara langsung membuka aplikasi whatsapp sesuai dengan akun yang ada pada whatsapp mobile. Ketika membuka whatsapp web, semua percakapan yang ada pada whatsapp mobile akan turut disajikan. Sinkronisasi akan dilakukan secara otomatis apabila terjadi perubahan pada salah satu aplikasi yang aktif.

Whatsapp dapat mengirim file-file seperti:

1. Foto. Berupa pesan gambar tidak bergerak yang direkam dapat diperoleh langsung dari dari kamera, file manager dan media galeri.

2. Video. Berupa pesan gambar bergerak yang direkam dapat langsung dari video kamera, file manager dan media galeri.

3. Audio. Berupa pesan suara yang direkam dapat langsung dari audio,file manager atau musik galeri.

4. Location. Berupa pesan keberadaan pengguna di suatu tempat dengan bantuan fasilitas Google Maps. Pesan ini memungkinkan penggunanya menjelaskan tempat ia berada dengan pengguna lain. 
5. Contact. Dapat mengirim detail nomor kontak dari buku telpon atau phonebook.

Fitur lain yang terdapat di Whatsapp adalah:

1. View Contact: dapat melihat daftar nama kontak dibuku telepon.

2. Avatar : dapat mengganti avatar atau tampilan profil secara manual. Whatsapp akan mengambil data avatar dari profile phonebook. Apabila menggunakan sinkronisasi Facebook dengan phonebook, maka avatar yang muncul adalah avatar Facebook.

3. Add conversation shortcut : dapat juga menambahkan shortcut conversation ke homescreen.

4. Email Conversation : menu ini bisa menyimpan percakapan pengguna dan mengirimkannya lewat email.

5. Grup Chat : penggunanya bisa membuat kelompok atau grup percakapan. Kemampuannya kini ditingkatkan hingga tiap grup kini mencapai 256 anggota.

6. Copy/Paste : Setiap kalimat perbincangan juga dapat digandakan atau copy, disebarkan atau forward dan dihapus atau delete dengan menekan dan menahan kalimat tersebut dilayar.

7. Emoji: Untuk menambahkan serunya perbincangan, tidak hanya menggunakan bahasa teks tapi juga dengan bahasa gambar sesuai ikonikon yang pengguna tampilkan sebagai pesan.

8. GIF: selain emoji, pengguna juga bisa mengirim animasi singkat dalam format GIF

9. Stiker: penggunanya sekarang bisa membuat stiker dengan foto diri.

10. Search : fitur dasar setiap Instan Messaging, Anda dapat mencari daftar contact melalui fitur ini. 
11. Whatsapp Call dan video call : karena verifikasi Whatsapp sama dengan nomor telepon selular pengguna lainnya. Penggunanya dapat melakukan panggilan langsung dari aplikasi Whatsapp ini dengan koneksi internet atau data.

12. Block: digunakan untuk memblok kontak tertentu.

13. Status : seperti kebanyakan fitur Instan Messaging, status juga hadir di Whatsapp. Namun tidak seperti BlackBerry Messenger yang menampilkan kondisi terbaru atau update setiap ada perubahan status dari teman, Whatsapp hanya menampilkan status dibawah nama teman, mirip dengan di Yahoo Messenger. Anda pun dapat mengganti status yang sudah tersedia di Whatsapp seperti available, busy, at school dan lain-lain.

Keuntungan menggunakan Whatsapp :

1. Tidak hanya teks : Whatsapp memiliki fitur untuk mengirim gambar, video, suara, dan lokasi GPS via hardware GPS atau Gmaps. Media tersebut langsung dapat ditampilkan dan bukan berupa link.

2. Terintegrasi ke dalam sistem : Whatsapp layaknya sms, tidak perlu membuka aplikasi untuk menerima sebuah pesan. Notifikasi pesan masuk ketika telepon selular sedang tidak aktif atau off akan tetap disampaikan jika telepon selular sudah aktif atau on.

3. Status Pesan : Jam merah untuk proses loading di telepon selular kita. Tanda centang jika pesan terkirim ke jaringan. Tanda centang ganda jika pesan sudah terkirim ke teman chat. Silang merah jika pesan gagal

4. Broadcats dan Group chat : Broadcast untuk kirim pesan ke banyak pengguna. Grup chat untuk mengirim pesan ke anggota sesama komunitas. 
5. Hemat Bandwidth : Karena terintegrasi dengan sistem maka tidak perlu login atau masuk dan loading contact/avatar, sehingga transaksi data makin irit. Aplikasi dapat dimatikan dan hanya aktif jika ada pesan masuk, sehingga bisa menghemat tenaga baterai telepon selular.

Melihat berbagai kemudahan dan manfaat yang ditawarkan, maka tak mengherankan jika Whatsapp digunakan oleh semua kalangan mulai dari remaja, dewasa, hingga yang tua. Whatsapp juga tidak terbatas oleh kelas sosial ekonomi tertentu, melainkan digunakan oleh semua kelas, mulai ekonomi rendah, menengah, hingga ekonomi atas.

Pada perkembangan selanjutnya, aplikasi Whatsapp ini tidak hanya dimanfaatkan untuk berkomunikasi dan bertukar pesan, akan tetapi saat ini Whatsapp juga dimanfaatkan untuk kepentingan pendidikan. Kelompok Bermain Permata Bunda desa Gesikharjo menggunakan aplikasi ini untuk berkomunikasi dengan orang tua wali murid. Guru biasanya memanfaatkan group chat yang tersedia dengan tujuan agar informasi yang disampaikan lebih menyeluruh tanpa harus mengirim informasi satu persatu. Selain itu, dengan adanya group chat tersebut komunikasi antara guru dan orang tua siswa bisa lebih efektif.

\section{Penyampaian Informasi Proses Belajar Anak}

Kontak antara guru dan orang tua sangat diperlukan dalam proses belajar anak. Kehadiran orang tua di sekolah secara otomatis dapat menjalin kontak dengan guru-guru di sekolah, meskipun kehadirannya tidak secara formal. Kontak antara orang tua dan guru tersebut dapat menjadi jembatan komunikasi yang bermanfaat bagi tumbuh kembang anak (Suyadi, 2012: 159). Bahkan, kontak tersebut dapat membuka kerjasama antara orang tua dan guru dimana hasilnya merupakan pengalaman pendidikan yang baik bagi anak. 
Keterlibatan orang tua dan guru di sekolah mempunyai banyak manfaat. Hasil-hasil riset telah menunjukkan bahwa pencapaian anak meningkat dengan adanya program keikutsertaan orang tua di dalam sekolah. Henderson dalam Suyadi (2012: 159) menyimpulkan beberapa hal berikut:

1. Keterlibatan orang tua dalam pendidikan formal anak meningkatkan pencapaian belajar anak

2. Keterlibatan orang tua lebih efektif jika dilakukan secara komprehensif dan terencana

3. Keterlibatan orang tua saat anak masih dalam usia dini mempunyai efek menguntungkan terhadap pencapaian akademik dimasa yang akan datang

4. Keterlibatan orang tua dalam pendidikan anak di rumah tidak cukup untuk meningkatkan kemampuan akademik anak dibandingkan dengan orang tua ikut serta di sekolah

5. Anak-anak dari ekonomi lemah akan mendapat menfaat dari program orang tua ikut serta dalam program sekolah

Mengingat banyaknya manfaat yang bisa diambil dari keikutsertaan orang tua, maka guru sebaiknya mengajak atau melibatkan orang tua dalam pendidikan anak di sekolah. Akan tetapi tidak semua orang tua mampu membersamai anak di sekolah karena kesibukan. Menurut Chris Athey dalam Suyadi (2012:157) setidaknya ada 5 jenis orang tua anak PAUD:

1. Orang tua yang berusaha mengenal dan mencoba memperluas pengalaman belajar anaknya

2. Orang tua yang ingin bekerja dengan guru di kelas dimana dia melihat metode guru kurang cocok untuk anaknya

3. Orang tua yang hadir di sekolah sepanjang hari tetapi tidak aktif dikelas 
4. Orang tua yang mengadakan kontak dengan sekolah mengantar dan menjemput anaknya ke sekolah serta seringkali menghadiri pertemuan orang tua

5. Orang tua yang tidak mengantar dan menjemput sendiri anaknya ke sekolah bahkan juga tidak mengadakan kontak dengan sekolah

Oleh karenanya orang tua yang kurang mengadakan kontak dengan guru di sekolah memerlukan komunikasi yang lebih intens. Komunikasi antara orang tua dan guru bertujuan untuk membangun kerjasama atau partnership untuk mengoptimalkan perkembangan anak. Selain itu, untuk memberikan informasi proses belajar anak di sekolah.

Penggunaan media informasi yang paling "trend" saat ini adalah dengan menggunakan group whatsapp. Melalui group ini guru mampu menyampaikan informasi secara langsung dan menyeluruh tentang aktivitas anak di sekolah. Menyampaikan informasi adalah bentuk dari komunikasi, sementara komunikasi berarti membangun interaksi antara orang tua dan guru. Menurut William Wilmot dalam Mulyana (2013: 67-77) dalam komunikasi terjadi proses sebab- akibat atau aksi-reaksi dimana penerima pesan menerima umpan balik. Misalnya, orang tua memberikan tanggapan terhadap informasi yang disampaikan guru, demikian pula guru yang memberikan tanggapan terhadap pertanyaan atau masukan dari orang tua.

\section{METODE}

Penelitian ini dilaksanakan di KB Permata Bunda Desa Gesikharjo. Jenis penelitian yang digunakan adalah deskriptif kualitatif dengan pendekatan studi kasus. Menurut Moleong penelitian deskriptif merupakan penelitian yang dimaksudkan untuk mengumpulkan informasi mengenai suatu gejala yang ada (1993: 165-166). Sedangkan menurut Bogdan dan Taylor mendefinisikan pendekatan kualitatif sebagai prosedur penelitian 
yang menghasilkan data deskriptif berupa kata-kata tertulis / lisan dari orangorang dan perilaku uang diamati (1975: 372). Adapun objek dalam penelitian ini adalah kepala $\mathrm{KB}$, guru, dan orang tua siswa.

Sementara pengumpulan data dilakukan dengan teknik observasi, wawancara tidak terstruktur, dan dokumentasi. Sedangkan instrumen yang digunakan adalah lembar observasi. Data yang telah diperoleh kemudian dianalisis dengan reduksi data, penyajian data, dan kesimpulan.

\section{HASIL DAN PEMBAHASAN}

\section{1) Penyampaian Informasi Proses Belajar Anak di KB Permata Bunda}

Ditengah persaingan global seperti sekarang ini, diperlukan penyelenggaraan pendidikan yang memberikan kesempatan seluas-luasnya kepada anak didik untuk tumbuh dan berkembang sesuai dengan potensi, minat, bakat, dan kesanggupannya. Sebab anak adalah asset bagi orang tua, dan di tangan orang tua lah anak-anak tumbuh dan menemukan jalannya (Maimunah, 2013: 29). Sejalan dengan hal tersebut, guru di KB Permata Bunda sangat memperhatikan tumbuh kembang anak didiknya. Hal-hal yang berkaitan dengan perkembangan siswa-siswinya akan dikomunikasikan dengan orang tua.

Ada beberapa hal yang dikomunikasikan dengan orang tua di $\mathrm{KB}$ Permata Bunda, diantaranya:

a. Informasi akademik tentang perkembangan anak. Perkembangan anak meliputi aspek fisik-motorik, kognitif, bahasa, social-emosional, seni, moral agama disampaikan melalui buku penghubung yang berisi laporan perkembangan anak yang dibagikan tiap tiga bulan sekali. Perkembangan anak ditandai dengan beberapa penilaian, misalnya BB 
(Belum Berkembang), MB (Mulai Berkembang), BSH (Berkembang Sesuai Harapan), BSB (Berkembang Sangat Baik).

b. Informasi kegiatan outing class. Kegiatan yang akan dilaksanakan di luar kelas biasanya diberitahukan 1-2 hari sebelumnya oleh guru melalui surat. Menurut Suryosubroto (2001:38) surat adalah media komunikasi tertulis yang berisi kebijaksanaan, peraturan, pemberitahuan, dan sebagainya. Berdasarkan observasi, guru memberikan surat kepada anak sehari sebelum outing class "membuat ayam goreng" di ASC Tuban. Surat tersebut diberikan kepada anak untuk disampaikan kepada orang tua. Menurut Hafied Cangara (2014: 42) komunikasi tersebut menunjukkan fungsi komunikasi, yaitu memberi informasi. Komunikasi dilakukan untuk memberikan informasi baik berupa pesan, gagasan, ide, opini, dan lain lain kepada penerima pesan, sehingga penerima pesan mengetahui informasi tersebut. Menurut Effendy dalam Trisnani (2017: 3) pesan adalah lambang bermakna (meaningful symbols), yakni lambang yang membawakan pikiran atau perasaan komunikator. Pesan adalah suatu materi yang dimiliki oleh sumber untuk dibagikan kepada orang yang lain. Dalam bentuknya merupakan sebuah gagasan yang telah diterjemahkan ke dalam simbol-simbol yang digunakan untuk menyatakan suatu maksud tertentu. Simbol-simbol tersebut bisa berupa kata-kata atau gambar yang digunakan oleh si pengirim pesan untuk menyatakan pengertian kepada penerima.

c. Informasi kegiatan yang membutuhkan anggaran dari orang tua. Pada dasarnya setiap kegiatan memerlukan anggaran. Akan tetapi, di KB Permata Bunda kegiatan-kegiatan outing class, misalnya kunjungan ke resto, kunjungan ke damkar dll, dananya diambil dari dana BOP. Biasanya orang tua hanya mengeluarkan biaya transport yang tidak 
terlalu besar. Sementara ada kegiatan lain yang membutuhkan dana lebih besar, misalnya kegiatan karnaval. Kegiatan semacam ini disampaikan secara langsung kepada orang tua dengan mengadakan pertemuan. Pertemuan wali murid ini juga bertujuan untuk memberikan kesempatan kepada orang tua yang notabene nya kurang berinteraksi dengan guru untuk bertanya atau memberikan masukan-masukan terkait informasi yang disampaikan

2) Pemanfaatan group whatsapp sebagai Media Informasi Proses

\section{Belajar Anak}

Hasil survei Global Web Index pada tahun 2016 menjelaskan bahwa setengah dari pengguna YouTobe menggunakan Whatsapp messenger. Survey ini juga menyebutkan bahwa frekuensi pengguna 6 media sosial tertinggi pada tahun 2016 adalah Whats App sebesar $60 \%$ kemudian diikuti oleh facebook sekitar $54 \%$. Berdasarkan hasil survei ini juga menjelaskan bahwa para pengguna Facebook dalam berbagi foto pun lebih banyak menggunakan Whatsapp messenger dibanding Facebook itu sendiri. Sekitar $75 \%$ facebooker berbagi foto lewat Whats App sementara lewat Facebook sekitar $49 \%$ saja (Andi, 2017: 6)

'Mudah' dan 'murah' yang ditawarkan oleh aplikasi whatsaap membuat berbagai kalangan banyak memanfaatkan aplikasi ini sebagai media informasi. Di KB Permata Bunda, group whatsapp digunakan untuk menyampaikan informasi proses belajar anak setiap harinya. Setiap hari guru selalu mengirim foto kegiatan anak di sekolah disertai dengan sedikit penjelasan tentang tema yang diajarkan. Guru akan mengambil gambar siswa saat sedang membuat karya, karya yang sudah jadi kemudian di foto oleh guru dan dikirim ke group whatsapp. Tidak hanya itu saja, kegiatan makan bersama di sekolah juga dilaporkan dalam bentuk foto. 
Selain itu, informasi yang biasanya mendadak atau terkait dengan pembelajaran esok hari akan disampaikan di group. Misalnya, anak disuruh membawa foto keluarga, membawa kardus bekas, kalender bekas dan sebagainya. Penyampaian informasi ini tidak serta merta diinformasikan kepada orang tua melalui group whatsapp. Saat pulang sekolah sebelumnya guru juga memberitahu anak-anak kegiatan dan alat apa yang harus dibawa untuk esok harinya. Hal ini bertujuan untuk melatih anak menyampaian pesan guru kepada orang tuanya.

Di KB Permata Bunda tidak semua orang tua siswa memiliki smartphone atau memakai whatsapp. Untuk mengantisipasi hal ini, informasi disampaikan melalui anak atau menitipkan pesan pada orang tua lain untuk diberitahukan ke orang tua tersebut. Berdasarkan wawancara dengan salah satu wali murid, orang tua merasa senang dan merasa dilibatkan dalam proses pembelajaran ketika guru memberikan informasi tentang anaknya.

\section{3) Dampak Positif dan Negatif dari Pemanfaatan Group Whatsapp sebagai Media Informasi}

Group whatsapp KB Permata Bunda Desa Gesikharjo menggunakan dua model group. Group pertama langsung dikendalikan oleh guru, dan group kedua dikendalikan oleh ketua paguyuban yang beranggotakan ibu-ibu wali murid. Semua informasi dari sekolah baik kebijakan sekolah maupun kebijakan kelas menjadi tanggungjawab guru/wali kelas dalam pemberitaannya. Dalam hal ini guru guru menjadi agen informasi. Dan bisa dipastikan kesibukan guru akan bertambah manakala ada orang tua siswa yang bertanya tentang informasi yang disampaikan. Sedangkan group yang hanya berisikan orang tua berfungsi untuk memberikan informasi diluar proses pembelajaran, seperti diskusi tentang membuat taman di sekolah, 
menjenguk siswa yang sakit, menjenguk guru setelah melahirkan, takziyah dan lain-lain yang lebih bersifat sosial.

Dari hasil wawancara dengan beberapa orang tua siswa, group whatsapp ini memberikan banyak keuntungan, diantaranya:

1) Informasi terkait dengan kegiatan pembelajaran di sekolah kepada orang tua menjadi cepat dan akurat;

2) Memudahkan orang tua yang mempunyai kesibukan untuk memantau kegiatan anak di sekolah;

3) Melalui group whatsapp, orang tua dengan mudah menanyakan proses pembelajaran dan perkembangan anak secara langsung;

4) Orang tua bisa melakukan komunikasi dengan guru kapanpun tanpa harus bertemu di sekolah;

5) Bisa melakukan diskusi tentang kegiatan yang akan diselenggarakan di sekolah dengan sesama orang tua.

Selain beberapa manfaat yang disebutkan, ada beberapa dampak negatif yang dihasilkan. Berdasarkan observasi dan wawancara dengan guru, diantaranya:

1) Guru harus menyediakan waktu lebih untuk membalas pesan yang masuk dari orang tua, yang terkadang pesan tersebut diterima saat sang guru sedang beristirahat

2) Komunikasi dengan lisan dan tulisan terkadang menimbulkan persepsi yang berbeda dari si pengirim dan penerima, misalnya guru menuliskan pesan dengan kata-kata yang disingkat atau sebaliknya;

3) Musyawarah yang terkadang tidak menemukan solusi, seperti menentukan jadwal makan bersama untuk anak-anak, dimana guru menghendaki ada makan bersama sebanyak 4 kali dalam satu minggu, sementara orang tua sebagian tidak menghendaki ada makan bersama, 
ada yang menghendaki satu minggu cukup sekali. Karena tidak menemukan solusi, guru memanggil seluruh wali murid untuk melakukan pertemuan;

4) Bahasa komunikasi seperti teman sendiri, dengan kata lain unggahungguhnya terhadap guru kurang.

Pada dasarnya banyak manfaat yang bisa didapat dari adanya group whatsapp ini, kerjasama dan pembinaan yang tepat antara orang tua dan guru berguna untuk meningkatkan perkembangan anak secara optimal yang kemudian hari akan berdampak pada peningkatan prestasi anak.

\section{PENUTUP}

\section{Simpulan}

Hasil penelitian menunjukkan bahwa informasi yang disampaikan kepada orang tua wali murid Kelompok Bermain Permata Bunda Gesikharjo meliputi hal-hal yang bersifat akademik, sementara yang bersifat non akademik atau kegiatan penunjang lain diserahkan kepada ketua paguyuban. Penyampaian informasi dilakukan sesuai kebutuhan kapan informasi tersebut perlu disampaikan. Beberapa manfaat bisa diperoleh orang tua, terutama yang berkaitan dengan perkembangan anak-anak mereka. Sedangkan musyawarah yang dilakukan di group apabila tidak ada titik temu maka kepala sekolah dan guru akan langsung mengadakan pertemuan dengan wali murid

\section{DAFTAR PUSTAKA}

Andi Miladiyah. (2017). Pemanfaatan Whatsapp Messenger Info dalam Pemberian Informasi dan Peningkatan Kinerja pada Sub Bagian Program Pemerintah Provinsi Sulawesi Selatan. Universitas Hasanuddin Makassar 
Interprise. (2012). Chatting Tanpa Batas Menggunakan Whatsapp. Jogjakarta:PT Alex MediaKomputindo

Maemunah Hasan. (2009). Pendidikan Anak Usia Dini. Yogyakarta: Diva Press.

Mulyana, D. (2013). Ilmu Komunikasi Suatu Pengantar. Bandung: PT Remaja Rosdakarya.

Seefeldt, C. \& Wasik, B. A. (2008). Pendidikan Anak Usia Dini: Menyiapkan Anak Usia Tiga, Empat, Lima Tahun Masuk Sekolah. Jakarta: PT INDEKS.

Suyadi, Maulidya Ulfah, Konsep Dasar PAUD. (2017). Bandung: PT Remaja Rosdakarya.

Trisnani. (2017). Pemanfaatan Whatsapp sebagai Media Komunikasi dan Kepuasan dalam Penyampaian Pesan di Kalangan Tokoh Masyarakat. Jurnal Komunikasi Media dan Informatika 6 (3). 